\title{
KAJIAN EKONOMI POLITIK BANTUAN MODAL MASYARAKAT MISKIN STUDI KASUS KEBIJAKAN BANTUAN DANA PELAKU USAHA MIKRO (UKM) DI KABUPATEN BANTUL
}

\author{
Wahyu Riawanti \\ Badan Ketahanan Pangan Propinsi DIY \\ e-mail: riawanti@hotmail.com
}

\begin{abstract}
Small and Medium Enterprises (SME) is the main sector to prevent developing countries from collapse during the economy crises. Meanwhile in Indonesia, not many policies in SME seem to stand in the right place in helping the SME actors especially the mikro business people. This research aimed to study about the implementation of government aid program in two sub-district in Bantul and how the micro business people perspective about those program. Using triangulation of qualitative and quantitative methods, this research tried to combine those insight and findings from the two different data sources. Result in early qualitative research of study has shown two main reasons of government aid program implementation characters: (a) inefective program caused by beureucrate and (b) distrust of community. The following quantitative research was organised to confirm and emphasize the indicators. Data of questionnaire confirmed that distrust of people came from the inefficient beaurocrate. It also emerged the fact about complexity of program came from the jealousy between beneficiaries has made the programs less efective.
\end{abstract}

Keywords: SME, microfinance, government program

\section{PENDAHULUAN}

Kajian kebijakan dengan pendekatan ekonomi politik pada dasarnya adalah penekanan pada keberpihakan. Keterbatasan sumber daya yang ada akan menyebabkan kebijakan berpihak pada satu kelompok, dengan demikian internvensi pemerintah diperlukan untuk menciptakan aturan main supaya pengelolaan sumber daya tidak menimbulkan konflik. Hal yang membedakan dengan ekonomi konvensional adalah bahwa dalam ekonomi politik, kajian ditekankan karena adanya kekuasaan yang mengontrol masyarakat sehingga kebijakan yang dibuat bisa jadi berpihak (Yustika, 2011:13).
Dalam implementasi kebijakan UKM ini, "keberpihakan" yang dimaksud menyangkut sejumlah anggaran pemerintah yang disalurkan dalam bentuk pelatihan dan bentuan berupa pinjaman modal maupun cash grant. Anggaran pemerintah sebesar 1,8 triliun disalurkan dalam bentuk sejumlah pelatihan dan bentuan baik berupa pinjaman modal maupun cash grant pada tahun 2014 (APBN, 2014). Implementasi program di dalam kementerian Koperasi UKM semestinya menjawab pertanyaan who gets what, sehingga bisa menjelaskan mengapa corak sektor dan pelaku UKM hari ini diwarnai dengan (a) jumlah usaha sebesar 53,8 juta dengan skala usaha mikro, dan (b) terbatasnya akses bagi pelaku 
usaha mikro, dan minimnya proteksi pemerintah bagi pelaku usaha menengah.

Tabel 1

Jumlah Unit Usaha dan Tenaga Kerja UKM 2010- 2011

\begin{tabular}{|c|c|c|c|c|c|c|c|}
\hline \multirow{2}{*}{ Indikator } & \multirow{2}{*}{ Satuan } & \multicolumn{2}{|c|}{ Tahun 2010} & \multicolumn{2}{|c|}{ Tahun 2011} & \multicolumn{2}{|c|}{$\begin{array}{l}\text { Perkembangan } \\
\text { tahun 2010-2011 }\end{array}$} \\
\hline & & Jumlah & $\begin{array}{c}\text { Pangsa } \\
(\%)\end{array}$ & Jumlah & $\begin{array}{c}\text { Pangsa } \\
(\%)\end{array}$ & Jumlah & $\%$ \\
\hline $\begin{array}{l}\text { UNIT } \\
\text { USAHA } \\
(\mathrm{A}+\mathrm{B})\end{array}$ & (Unit) & 53.828 .569 & & 55.211 .396 & & 1.382 .827 & 2,57 \\
\hline $\begin{array}{l}\text { A. Usaha } \\
\text { Mikro, } \\
\text { Kecil \& } \\
\text { Menengah } \\
\text { (UKM) }\end{array}$ & (Unit) & 53.823 .732 & 99,99 & 55.206 .444 & 99,99 & 1.382 .713 & 2,57 \\
\hline $\begin{array}{l}\text { - Usaha } \\
\text { Mikro } \\
\text { (UMi) }\end{array}$ & (Unit) & 53.207 .500 & 98,85 & 54.559 .969 & 99 & 1.352 .470 & 2,54 \\
\hline $\begin{array}{l}\text { - Usaha } \\
\text { Kecil } \\
\text { (UK) }\end{array}$ & (Unit) & 573.601 & 1,07 & 602.195 & 1,09 & 28.594 & 4,98 \\
\hline $\begin{array}{l}\text { - Usaha } \\
\text { Menengah } \\
\text { (UM) }\end{array}$ & (Unit) & 42.631 & 0,08 & 44.280 & 0,08 & 1.649 & 3,87 \\
\hline $\begin{array}{l}\text { B. Usaha } \\
\text { Besar } \\
\text { (UB) }\end{array}$ & (Unit) & 4.838 & 0,01 & 4.952 & 0,01 & 114 & 2,35 \\
\hline $\begin{array}{l}\text { TENAGA } \\
\text { KERJA } \\
(\mathrm{A}+\mathrm{B})\end{array}$ & (Orang) & 102.241 .486 & & 104.613 .681 & & 2.372 .196 & 2,32 \\
\hline $\begin{array}{l}\text { A. Usaha } \\
\text { Mikro, } \\
\text { Kecil } \\
\text { Menengah } \\
\text { (UKM) }\end{array}$ & (Orang) & 99.401 .775 & 97,22 & 101.722 .458 & 97,24 & 2.320 .683 & 2,33 \\
\hline $\begin{array}{l}\text { - Usaha } \\
\text { Mikro } \\
\text { (UMi) }\end{array}$ & (Orang) & 93.014 .759 & 90,98 & 94.957 .797 & 90,77 & 1.943 .038 & 2,09 \\
\hline $\begin{array}{l}\text { - Usaha } \\
\text { Kecil } \\
\text { (UK) }\end{array}$ & (Orang) & 3.627 .164 & 3,55 & 3.919 .992 & 3,75 & 292.828 & 8,07 \\
\hline $\begin{array}{l}\text { - Usaha } \\
\text { Menengah } \\
\text { (UM) }\end{array}$ & (Orang) & 2.759 .852 & 2,70 & 2.844 .669 & 2,72 & 84.816 & 3,07 \\
\hline $\begin{array}{l}\text { B. Usaha } \\
\text { Besar } \\
\text { (UB) }\end{array}$ & (Orang) & 2.839 .711 & 2,78 & 2.891 .224 & 2,76 & 51.513 & 1,81 \\
\hline
\end{tabular}

Sumber : Kementerian Koperasi dan UKM, 2012 dalam www.depkop go.id

Jumlah usaha mikro yang merupakan angka terbesar dari total UKM dan besarnya tenaga kerja yang tertampung menjelaskan dominasi masyarakat miskin yang berada dalam kelompok ini. Pengembangan UKM dan sektor informal adalah solusi khas negara berkembang pasca reformasi setelah keterpurukan saat terjadi krisis ekonomi. UKM yang merupakan 99\% dari bentuk usaha masyarakat harus dibaca sebagai fakta yang mewakili urgensi peran pemerintah. Besarnya jumlah pelaku bisnis kecil ini sebenarnya juga merupakan besaran potensinya untuk menjadi gerakan sosial. Perputaran jumlah modal tersebut tidak sebanding dengan pangsa modal dari total jumlah UKM yang menampung $97,22 \%$ tenaga kerja atau sebanyak 102,2 juta pekerja Indonesia (Tabel 1).

UKM pun tidak bisa menegasikan globalisasi dan bersentuhan dengan perdagangan internasional. Usaha menengah di Indonesia harus berhadapan dengan minimnya proteksi pemerintah terhadap barang impor yang sejenis. Bagi umumnya negara berkembang dengan keterbatasan teknologi dan kapasitas produksi dibandingkan negara maju, membanjirnya produk impor menyebabkan permintaan terhadap produk lokal menurun, turunnya permintaan produk lokal menyebabkan meningkatnya jumlah pengangguran. Fakta ini yang disebut sebagai "tragedi perdagangan bebas" bagi negara berkembang (Suparmoko, 2002).

\section{REVIEW LITERATUR DAN HIPOTESIS}

\section{UKM dan Intervensi Pemerintah}

Kajian ekonomi politik UKM yang sangat menarik dilakukan oleh Timberg (2000) beberapa saat setelah reformasi Indonesia. Menurutnya tipikal kebijakan UKM di Indonesia adalah adanya "konsensus yang menyembunyikan disensus". Ada banyak pendekatan dari kelompok berbeda yang bertikai di sana; dari pendekatan akademis, kelompok kepentingan, partai politik dan institusi pemerintah. Pertanyaan naïf yang sering dilotarkan adalah "berada di manakah sebenarnya entitas UKM ini?’. Pertanyaan ini dilontarkan karena sosok UKM baik pelaku maupun bentuk usaha yang dimaksud seringkali demikian berserak, sehingga tidak benar-benar dihitung, melainkan ada karena eksistensinya diperlukan bagi kepentingan institusi tertentu (Timberg 2000: 3).

Pada masa pasca reformasi, kebijakan dan program UKM yang didanai oleh pemerintah maupun donor asing masih mencari bentuknya. 
Dalam rangka mencari bentuk tersebut diwarnai dengan dinamika persaingan "paradigma baru dan lama". Paradigma baru lebih banyak dianut oleh donor program UKM dari Eropa dan Amerika, sementara masyarakat dan LSM Asia lebih memilih paradigma lama yang dianggap lebih berempati. Pada masa pasca reformasi tersebut terminologi kredit UKM Indonesia mengadopsi program skema kredit pertanian karena sektor ini telah lebih lama memiliki Penyuluh Pertanian sehingga menguasai mekanisme program pemberian kredit dan bantuan input dari pemerintah. Meski demikian pada saat itu disepakati bahwa UKM hanya akan dapat berkembang dengan keseriusan mengedepankan tujuan yang jelas, eksekusi yang efisien, dan laporan yang transparan (Timberg 2000: 11). Kelak terbukti bahwa ketidaksuksesan program UKM ini terjadi karena pelanggaran kesepakatan ini. Pasca 1998, dengan makin bergesernya paradigma UKM menjadi lebih "market oriented", banyak donor dari lembaga domestik dan internasional tertarik pada sektor ini.

\section{Tinjauan Empiris UKM}

Jumlah usaha mikro sebesar 97\% dari total usaha di Indonesia menjelaskan mengapa angka kemiskinan di Indonesia tetap tinggi. Dalam artikel ini UKM yang dimaksud adalah usaha kecil dan mikro yang tidak kaku mengacu pada terminologi UKM menurut definisi formal. Banyaknya jumlah UKM tersebut semestinya dapat dibaca sebagai kekuatan rakyat. Meski demikian sektor informal ini hanya kuat pada sisi kuantitas karena tidak ada basis organisasi yang kuat. Pelaku usaha kecil tidak memiliki status yang jelas dalam hal pekerjaan karena tidak bekerja untuk sektor industri formal. Apakah UKM dapat meningkatkan pendapatan masyarakat di tengah arus pasar global? Pemerintah dengan kebijakannya mencoba meyakinkan bahwa hal tersebut benar adanya. Tetapi di lain pihak kompetisi dan partisipasi pasar internasional menyebabkan pola yang berbeda, yang menyebabkan UKM di negara berkembang tidak mendapatkan manfaat dengan ide besar pasar global tersebut (Pietrobelli et al., 2010: 16). Dengan demikian hanya negara lah yang bisa menjalankan peran dan daya paksa untuk setidaknya mengatur untuk mengurangi tekanan kompetisi tersebut.

Dengan semangat untuk menjadi global itulah kemudian muncul gagasan Kementerian Koperasi dan UKM, salah satunya dengan ide one village one product. Ide ini justru bisa menjadi gagasan yang berbahaya jika dipaksakan hanya karena berkiblat pada keberhasilan China. Industri di China dengan manufaktur raksasanya memungkinkan setiap desa memproduksi produk yang berbeda sehingga memiliki identitas produksi masing-masing. Hal ini tidak bisa begitu saja diterapkan di Indonesia karena kondisi sosial budaya masyarakat yang berbeda sehingga penyeragaman tidak mungkin dilakukan.

Salah satu indikator sosial tersebut adalah adanya social capital. Penelitian tentang modal sosial sebagai corak masyarakat dalam lingkup lebih kecil dilakukan oleh Turner (2007) yang meneliti UKM dan livelihood di Makasar Sulawesi, hasil penelitiannya menuntut pemerintah untuk memahami keunikan setiap daerah sehingga pemerintah tidak melakukan copy paste kebijakan. Di sisi lain, temuan penelitian ini menunjukkan betapa pun kuatnya modal sosial yang dapat menjembatani UKM dan livelihood di Makasar Sulawesi, dia tidak bisa memiliki kekuatan signifikan pada pemerintah yang korup. Ketika korupsi menjadi penyakit utama yang demikian menyebar, maka kekuatannya akan menghambat perkembangan UKM dan pengusaha lokal yang manapun (Turner 2007: 23).

Ciri lain dari karakter UKM Indonesia adalah rendahnya adopsi teknologi (Sarosa, 2007) sehingga jenis UKM tidak bisa ditentukan oleh penguasa karena membutuhkan teknologi 
informasi yang memadai. Seringkali pemerintah bersembunyi di belakang alasan kualitas pelaku UKM Indonesia karena memang pemerintah harus realistis akan ketertinggalan bangsa ini. Dalam studi perbandingan UKM di berbagai negara, asesmen yang dilakukan di Indonesia melaporkan adanya performan yang cukup baik dengan indikasi bawahan yang dapat menyampaikan pendapatnya kepada atasan. Masalah utama Indonesia berada pada ranah produktivitas dan kualitas. Misalnya dilaporkan oleh Bennington \& Habir (dalam Chandrakumara, 2013: 10) di mana output pekerja Indonesia sebesar seperempat dari pekerja Korea, dan sepersepuluh dibandingkan pekerja AS. Meski demikian dalam kajian tersebut belum dibandingkan antara unit labor cost. Jika komparasi dilakukan dengan indikator biaya tenaga kerja tersebut, maka pekerja Indonesia tiga kali lebih produktif dibandingkan pekerja Amerika, dan dua kali lipat produktivitas pekerja Korea.

Pendekatan ekonomi politik selalu menekankan pada siapa yang diuntungkan dalam suatu kebijakan. pendekatan ini paling efektif untuk membedah mengapa pemerintah melakukan suatu program yang sekian lama dianggap tidak efektif, dan seharusnya apa yang semestinya dilakukan (what should be set) (Shvet, 2101).

Kebijakan public is untidy process sehingga untuk menjawab whose interest counts, maka harus dilihat pada titik ini siapa saja yang berperan. Dengan melihat fenomena empiris yang menempatkan birokrat sebagai faktor utama penyebab dua masalah di atas, maka teori yang paling mendekati untuk menjelaskan fenomena ini adalah teori niskanen yang mempertanyakan peran birokrasi. pertanyaan utama niskanen tertuang dalam judul bukunya yang fenomenal yaitu "bureaucracy: servant or master?". teori niskanen kemudian menelusur pemikiran yang banyak membahas dan meneliti tentang birokrasi.

Klaim utama Niskanen (1971) pada kajiannya tentang keterbatasan pemerintah admi- nistratif adalah bahwa (a) birokrasi sedemikian rupa sudah dikuasai oleh "daya tarik" memaksimalkan sumber daya (anggaran) dan bahwa (b) kemampuannya untuk memonopoli distribusi jasa dan barang publik yang menjadikannya tidak efisien dan tidak responsif baik terhadap warga negara maupun terhadap preferensi politik, seperti dalam kutipan berikut:

...bureaucracy is preoccupied with resource (budget) maximization and that its monopoly power over the distribution (administration) of the supply of public goods and services made it inefficient and unresponsive to both citizen and politician preferences.

Lebih lanjut Niskanen menggagas dan menggarisbawahi pendekatan yang berbasispasar yaitu dalam hal "equilibrium dan marginal utility” (Niskanen, 1971; Bendor, 1990). model niskanen ini berbasis pada kebijakan tingkat federal pusat dengan dua pemeran yaitu legislature atau wakil rakyat yang digambarkan menjadi wakil "pembeli" dan agencies yaitu pemerintah sebagai pelaksana eksekutif sebagai penyedia jasa atau supplier, di mana keduanya berada di level pusat (Bendor, 1990). penekanan dalam teori ini adalah pembentukan kebijakan yang bersifat organizational (Allison, 1971) terkait dengan alokasi anggaran.

Selanjutnya model niskanen berlanjut pada fokus pilihan publik tentang bagaimana $d e$ mand para pembuat keputusan kemudian mempengaruhi sisi supply-nya. "pilihan publik" dan pendekatan niskanen dengan "marginal utility" tersebut memiliki titik pandang yang menekankan pada demand dan respon terhadap demand tersebut. Niskanen dan pengikutnya kemudian meninggalkan gagasan yang terbuka bagi siapa saja, yaitu: apakah pemerintah (sebagai penjual, dalam konteks ekonomi) akan bertindak proaktif dalam mengumpulkan informasi, mengembangkan dan memasarkan suatu produk kebijakan. 
Tulisan Beckett (2000) kemudian mengembangkan pemikiran William Niskanen tersebut menggunakan pendekatan inkremental (incremental) yang yang menjelaskan bahwa dalam mendeskripsikan keputusan/ kebijakan pemerintah terkait budget dalam hal alokasi, produksi dan provisi. Tiga hal ini adalah bentuk wajib intervensi pemerintah sebagai negara, dalam hal ini penting dilakukan terkait keputusan penganggaran dan pertanyaan tentang bagaimana inkremental tersebut bisa dijadikan penyesuaian bagi perbandingan baik internal maupun eksternal. Salah satu pendekatan untuk menerapkan metafora ekonomi dan konsep tersebut adalah apa yang disebut dengan "the niskanen tradition" yaitu dalam proses penetapan buget/anggaran. kemudian Tullock and Buchanan melanjutkan pandangan ini dengan menganggap bahwa scretional self-interest (yang merupakan roh dari segala tindakan ekonomi) suatu individu akan mempengaruhi pilihan mereka dalam menentukan pelayanan pemerintah dan pajak yang dikutip pemerintah (buchanan and tullock, 1962). Jika pola tersebut dibandingkankan dengan kebijakan UKM di Indonesia, maka jelas dapat dilihat gambarannya. Tingginya anggaran untuh hibah dana dan pinjaman modal tak lain hanya menguntungkan birokrat dan perangkat desa.

Sementara masyarakat miskin tidak mendapatkan haknya, kemudahan regulasi justru dinikmati oleh pengusaha ritel modern. pertanyaan penting dalam konteks ini adalah: di mana cost yang harus dibayar ketika MNCS mendapat kemudahan beroperasi di indonesia. Kemudahan bagi MNCS selalu berarti ketidakmudahan bagi usaha mikro, dan masih ditambah perilaku oknum pemerintah justru memanfaatkan UKM dan koperasi sebagai kendaraan untuk kepentingan pribadi maupun golongan (partai politik).

Kritik terbesar Tullock dalam kajiannya tentang goods, redistribution and rent seeking adalah bahwa income terbesar hampir tidak pernah didistribusikan untuk masyarakat miskin
(Tullock, 2005: 92), padahal setiap warga negara yang memberikan suaranya (vote) melalui aktivitas politik (pemilu) untuk mendapatkan transfer (keuntungan) kembali. Income inilah yang tidak hanya terbaca dalam kutipan tidak resmi dari bansos tetapi lebih luas lagi berupa kerugian sosial (social loss) yang harus ditanggung oleh masyarakat ketika program yang dijalankan tidak berjalan efisien.

Masalah terbesarnya kemudian adalah sejumlah besar keuntungan dinikmati oleh mereka yang bahkan tidak berinvestasi apapun, seperti oknum aparat birokrat dan pelaku usaha yang mendapatkan keuntungan karena kebijakan yang berpihak pada pemilik modal. dalam aktifitas ekonomi, keuntungan didapat karena ada kegiatan investasi yang dilakukan, baik dalam bentuk investasi fisik perusahaan/toko, kemampuan intelegensi para profesional, maupun kerja keras (buruh), dengan demikian jika kebijakan tidak menguntungkan pelaku usaha mikro semestinya ada pelaku lain yang diuntungkan dan salah satunya adalah MNCS. Pertanyaannya kemudian adalah siapa yang membayar biaya (social cost) tersebut sehingga pihak tertentu diuntungkan? inilah bagian dari biaya sosial yang harus dibayar ketika mereka yang tidak melakukan investasi dan bukan profesional maupun buruh justru mendapatkan banyak keuntungan. Dalam konteks ekonomi murni hal ini bisa dijelaskan, tetapi secara etika dan pendekatan ekonomi politik masyarakat tidak akan bisa menerimanya.

Tentu saja setiap daerah memiliki coraknya sendiri dalam implementasi kebijakan, demikian pula halnya dengan kebijakan terkait UKM. Hasil penelitian di Denpasar timur Bali menunjukkan bahwa program bantuan kredit usaha rakyat di kelurahan Penatih Dangin Puri kecamatan Denpasar Timur dikatakan cukup efektif yaitu sebesar 78,5 persen dan berdampak positif terhadap peningkatan pendapatan dan kesempatan kerja UKM (Budiani, 2009). sedangkan penelitian pada 85 kelompok swadaya 
masyarakat di Depok (Elida, 2011) menunjukkan efektivitas pengelolaan dana termasuk pada kategori minimum, hal ini dipengaruhi oleh tidak lancarnya tingkat pengembalian dana.

Dengan pemaparan di atas maka untuk menjawab pertanyaan utama Niskanen is bureaucrat servant or master, barangkali jawabannya adalah bahwa pada titik ini birokrasi menjalankan perannya sebagai pelayan bagi kapital besar melalui pemerintah, tetapi di saat yang sama juga menjadi majikan bagi rakyatnya sendiri. Hal tersebut kemudian menjawab pertanyaan kepada siapa pemerintah berpihak dan mengapa masyarakat miskin mempertanyakan dan menuntut pelayanan pemerintah sebagai pelayan masyarakat dan pelaksana program kebijakan.

\section{METODE PENELITIAN}

Penelitian ini memakai pendekatan triangulasi metode yaitu mencoba menggabungkan antara metode kualitatif dan kuantitatif. Sesuai dengan definisi triangulasi oleh Norman K. Denkin (dalam Rahardjo, 2010) yaitu sebagai gabungan atau kombinasi berbagai metode yang dipakai untuk mengkaji fenomena yang saling terkait dari sudut pandang dan perspektif yang berbeda. Konsep Denkin ini dipakai oleh para peneliti kualitatif di berbagai bidang dengan triangulasi yang meliputi empat hal, yaitu: (1) triangulasi metode, (2) triangulasi antar-peneliti pada penelitian kelompok, (3) triangulasi sumber data, dan (4) triangulasi teori.

Metode kualitatif dilakukan pada awal penelitian untuk memberikan gambaran implementasi kebijakan dan membuat hipotesis awal berdasarkan inisiasi penelitian. Data primer didapatkan dari in-depth interview pelaku usaha mikro, aparat pemerintah eksekutor program, dan aktivis lembaga swadaya masyarakat.

Selanjutnya data primer dengan metode kuantitatif diperoleh dengan bantuan kuesioner. Populasi penelitian merupakan pelaku usaha mikro di Kabupaten Bantul. Pengambilan sampel dilakukan dengan purposive sampling pada dua Kecamatan. Pertimbangan yang digunakan adalah responden merupakan pelaku usaha mikro yang aktif dan tersebar di dua kecamatan tersebut. Dari dua kecamatan di Kabupaten Bantul tersebut penelitian menentukan 8 dengan jumlah pelaku UKM terbesar sebagai lokasi pengisisn kuesioner. Data kuesioner didapatkan dengan bantuan staf peneliti karena keterbatasan responden untuk mengiterpretasikan pertanyaan kuesioner dalam Skala-Likert.

Tabel 2

\section{Distribusi Kuesioner}

\begin{tabular}{|c|c|c|c|}
\hline No & Desa & $\begin{array}{c}\text { Jumlah } \\
\text { Kuesioner }\end{array}$ & $\begin{array}{c}\text { Kuesioner } \\
\text { dengan data } \\
\text { lengkap }\end{array}$ \\
\hline 1 & $\begin{array}{l}\text { Sumber } \\
\text { Agung, Jetis }\end{array}$ & 20 & 20 \\
\hline 2 & Patalan, Jetis & 21 & 20 \\
\hline 3 & Canden, Jetis & 25 & 24 \\
\hline 4 & $\begin{array}{l}\text { Trimulyo, } \\
\text { Jetis }\end{array}$ & 20 & 20 \\
\hline \multirow[t]{2}{*}{5} & $\begin{array}{l}\text { Gedongsari, } \\
\text { Pandak }\end{array}$ & 20 & 18 \\
\hline & Jumlah & 106 & 102 \\
\hline
\end{tabular}

Sumber: Data primer, diolah.

\section{Definisi Operasional dan pengukuran variabel}

Variabel penelitian ini adalah persepsi responden terhadap bantuan dana terkait UKM dari pemerintah yang pernah diterima atau diimplementasikan di masing-masing lokasi. Dengan bantuan peneliti lapangan, responden harus menunjukkan pendapatnya dengan SkalaLikert 1 sampai 5. Angka 1 menunjukkan kategori "sangat tidak penting". Angka 2 menunjukkan kategori "tidak penting". Angka 3 menunjukkan kategori "ragu-ragu". Angka 4 menunjukkan kategori " penting". Angka 5 menunjukkan kategori "sangat penting". Persepsi responden tersebut diturunkan menjadi tiga variabel yaitu (1) penyelenggara kebijakan, (2) konten program 
dan (2) transparansi dan pendekatan personal petugas.

Kuesioner tentang penyelenggara kebijakan berisi 5 butir pertanyaan, konten program dikembangkan dalam 3 butir pertanyaan dan transparansi diturunkan menjadi 2 butir Angka 1 menunjukkan kategori "sangat tidak penting" Berikutnya hasil penelitian berupa wawancara (in-depth interview) dan data kuesioner digabungkan untuk analisis. Masing-masing cara ini menghasilkan bukti atau data yang berbeda, yang selanjutnya akan memberikan pandangan (insights ) yang berbeda pula mengenai fenomena penelitian. Pandangan dari sumber data yang berbeda memberikan keleluasaan peneliti untuk memperoleh kebenaran yang lebih handal.

Tujuan pemakaian triangulasi ini meningkatkan kedalaman pemahaman baik mengenai fenomena yang diteliti maupun konteks di mana fenomena itu muncul. Pemahaman yang mendalam (deep understanding) diharapkan akan bisa membantu untuk menangkap arti (meaning) atau memahami gejala, peristiwa, fakta, kejadian, realitas atau masalah penelitian dengan kompleksitasnya secara mendalam, dan tidak sekedar menjelaskan ( to explain ) atau membuktikan hubungan sebab akibat atau korelasi dari masalah penelitian.

\section{PEMBAHASAN DAN HASIL}

\section{Kebijakan UKM untuk Siapa}

Analisis dalam kajian ini terutama untuk menjawab bagaimana undang-undang tentang UKM tersebut dapat mengakomodir kepentingan pelaku UKM yang sebagian besar adalah masyarakat miskin. Komparasi antara undangundang dan program utama UKM menghasilkan setidaknya dua hal yang menjadi masalah yang menempatkan masyarakat miskin dalam regulasi terkait usaha mikro.

Masalah pertama adalah salah sasaran terkait beneficiary suatu program. Dalam program baru yang diberikan pemerintah sejak 2011 yaitu pinjaman modal PNPM diberikan langsung kepada pelaku UKM di kelurahan. Di beberapa desa di Kasihan Bantul pelaku usaha mikro sebenarnya tidak mendapatkan informasi tentang dana bantuan ini. Hasil wawancara yang dilakukan terhadap 12 wanita pelaku usaha mikro menunjukkan tidak adanya akses untuk mendapatkan dana yang dimaksud. Salah satunya disebabkan karena data warga miskin yang tidak konsisten sehingga tidak semua warga miskin mendapatkan kesempatan yang sama untuk mendapatkan bantuan. Sebaliknya dana lebih banyak diberikan untuk "kerabat dan kenalan Bu Dukuh", yang artinya diterima oleh kelompok masyarakat yang kurang tepat (PPMK, 2012). Bukti lapangan ini merupakan kesalahan pemerintah karena tidak memenuhi cita-cita pengaturan UKM yang menyebutkan dalam UU No 20/2008 Pasal 6 ayat (c) yaitu bahwa pemerintah akan memberikan jaminan transparansi dan akses yang sama bagi semua pelaku Usaha Mikro, Kecil, dan Menengah atas segala informasi usaha.

Menurut hasil wawancara dengan narasumber dari PPMK, masalah yang paling sering ditemukan bukan pada pengembalian modal, tetapi: (a) resistensi warga karena pengalaman dengan lembaga lain termasuk program pemberian bantuan modal dari pemerintah (b) skeptisme pelaku usaha mikro karena tidak pernah dilibatkan sebagai beneficiary (c) sebagian kecil (9\%) tidak adanya kesadaran untuk mengembalikan pinjaman tepat waktu.

Satu hal penting yang juga patut dicatat adalah, bahwa pelaku UKM sebagai beneficiary terutama perempuan membutuhkan pendekatan personal dengan lembaga pemberi dana, baik berupa pinjaman maupun setengah charity. Hal tersebut sangat penting bagi keberhasilan program dan menjaga kelanjutan hubungan yang baik. Yang lebih menarik adalah bahwa lembaga ini tidak mau menjadi besar dengan alasan untuk 
tetap menjaga hubungan personal dengan para nasabahnya yang jumlahnya terbatas.

\section{Inefisiensi Anggaran dan Ketidakpercayaan Masyarakat}

Dana bantuan yang disalurkan secara tidak tepat menyebabkan inefisiensi anggaran yang tidak dapat dihindari. Sementara itu kebijakan regulasi yang tidak memudahkan UKM kemudian menimbulkan ketidakpercayaan masyarakat kepada pemerintah. Dari paparan bukti empiris di atas, kedua masalah tersebut bermuara pada faktor birokrat. Di lain pihak program bantuan dalam bentuk subsidi input maupun cash grant pemerintah berupa Bantuan Tunai Langsung (BLT) tersebar melalui sejumlah kementerian berbeda. Hal ini menjadikan alasan bagi beberapa pemimpin daerah untuk membabat habis program inkremental yang bersifat rutin seperti yang yang dilakukan Pemda DKI. Program rutin tersebut berpotensi menciptakan program yang salah sasaran karen sifatnya "rutin' dan hafalan".

Karena bersifat rutin, mekanisme pemberian bantuan menjadi seperti kerja mesin birokrat yang berulang. Dana bantuan diberikan pada orang atau kelompok yang sama berpotensi untuk menciptakan pola kerjasama yang menguntungkan self-interest pemberi dana sehingga hal ini menimbulkan ketidakpercayaan masyarakat. Ketidakpercayaan dari masyakarakat ini tercermin dari respon masyarakat sebagai beneficiaries suatu program. Masyarakat memiliki komitmen lebih tinggi ketika bekerjasama dengan institusi keuangan/ simpan pinjam dengan pinjaman bunga rendah. Sebaliknya, masyarakat cenderung permisif dan tidak berkomitmen ketika mendapat bantuan pinjaman modal tanpa bunga dari pemerintah.

Inefisiensi dan ketidakpercayaan tersebut pada akhirnya menjadi alasan utama mengapa sampai menjelang pemerintah yang baru pada tahun 2014 karakter UKM Indonesia masih saja sama. Ciri tersebut adalah (1) keterbatasan akses terutama modal karena birokrat yang lebih mendahulukan kepentingannya, (2) untuk mendorong kepentingan tersebut maka kelembagaan koperasi dan UKM lebih bersifat top down sehingga tidak mendapatkan dukungan dari pelaku yang semestinya menjadi subyek di dalamnya, dan (3) pada akhirnya usaha mikro mengalami marjinalisasi. Secara umum usaha mikro masih terpinggirkan terutama karena keterbatasan akses baik dalam hal modal, pemasaran, maupun teknologi. Secara kinerja, kualitas dan kelembagaan pelaku mikro yang tidak cukup kuat menyebabkannya semata-mata menjadi obyek bagi program yang menguntungkan birokrat.

Kedua ciri ini dikonfirmasi dengan hasil penelitian. Salah satu hasil Focus Group Discussion dengan beneficiary program bantuan dana menunjukkan bagaimana kepentingan aparat pemerintah dalam memotong bantuan sebesar $30 \%$. Program dan kebijakan yang masih kental intervensi pejabat desa membuat suatu program menjadi bias sasaran dan tidak efektif seperti dalam kutipan diskusi berikut:

Kami rak Cuma mengikuti jare Pak Dukuh. Wong dulu pernah to bu... Saya ini ditanting sama Pak Dukuh lama: "piye tak golekke pinjaman 1 juta ning potongane 300 ewu" Saya jawab "Ya terserah, sesuk nek oleh dicowok (dipotong) wae 300 ribu, pak Dukuh bilang: nek ngono kuwi rasah rembugan (tidak setuju dengan caranya).... Yo wis, suk wae nek pas nyumbang nggone Kandar (diserahkan uangnya). Akhirnya beneran mbak, pas pulang dari nyumbang kula diadang (saya dicegat) dan saya serahkan 300 ribunya pada pak Dukuh...

Rendahnya kesadaran dan dukungan aparat merupakan salah satu kelemahan birokrasi yang menyebabkan inefiseiensi. Argumen dari perilaku penyakit birokrasi tersebut salah satu- 
nya ditunjukkan dalam hasil wawancara dengan istri Kepala Dusun (BU Dukuh) dalam FGD yang sama. Aparat cenderung melihat pekerjaan mengusahakan bantuan sebagai suatu beban. Sehingga setiap bagian pekerjaan pejabat birokrat tersebut adalah usaha yang harus dibayar dengan kompensasi dari dana bantuan, seperti dalam petikan wawancara ${ }^{1}$ berikut:

Bapak saya (Bapak mertua, merupakan Kepala Dusun sebelumnya) kan memang bertugas membentuk kelompok (sebagai penerima bantuan), Mbak... Dan itu pakai modal, biaya. Paribasane nek ora ono duite Bapak yo ra bakal nampa duit 1 juta. (Ibaratnya, kalau tidak ada uang dari Bapak untuk membuat dan mengajukan proposal, warga tidak akan menerima bantuan sebesar masingmasing 1 juta)...

Hubungan antara warga dan pemimpin dusun yang masih menjunjung tinggi kekerabatan sering menyebabkan bias pada saat suatu tindakan tegas perlu dilakukan. Warga masih merasa terintimidasi dan "tidak pantas" ketika harus ada tindakan hukum, meskipun mereka keberatan terhadap suatu kebijakan seperti pungutan 300 ribu dalam kasus di atas. Ketika masyarakat menuntut keadilan dan transparansi suatu kegiatan, pada saat yang sama kepentingan pribadi menuntut mereka untuk memperoleh keuntungan dari program yang sebenarnya bukan hak yang bersangkutan, seperti tercermin dalam kutipan berikut:

Lha kalau tidak (kalau raskin tidak dibagi rata), orang kayak saya ini nggak pernah menerima apa apa Mbak...Data pusat itu tidak tahu kalau ada warga baru yang lebih miskin. Tapi dibagi rata juga semua mau. Wong yang merasa sugih, terus dibalekke (dikembalikan) ya ada cuma 1 orang, itupun sing wedok sakjane gelem nampa, ning diseneni sing lanang ${ }^{2} .$.

\section{Variabel Bantuan yang Penting Untuk Masyarakat}

Hasil penelitian awal dikonfirmasi dengan melakukan pengukuran persepsi penerima bantuan dengan tiga variabel yaitu Penyelenggara Kebijakan, Konten Program dan variabel Petugas. Untuk variabel Penyelenggara Kebijakan dapat dilihat dalam Tabel 3. Dari tabel tersebut dapat dilihat untuk tiga item dalam variabel t-hitung lebih basar dari t-tabel. Data tersebut dapat menjadi dasar informasi dan konfirmasi bahwa responden menganggap tiga hal terkait penyelenggara kebijakan berikut merupakan hal yang paling penting dalam suatu program, yaitu: (a) cara menentukan penerima bantuan, (b) peran aparat desa, dan asal usul data untuk menentukan penerima bantuan.

\section{Tabel 3}

T-test Per Item untuk Variabel Penyelenggara Kebijakan $^{3}$

\begin{tabular}{|c|c|c|c|c|c|c|c|}
\hline \multirow{3}{*}{ No. } & \multirow{3}{*}{ Item pertanyaan } & \multicolumn{6}{|c|}{ T-Test } \\
\hline & & \multirow[b]{2}{*}{$\mathrm{T}$} & \multirow[b]{2}{*}{ Df } & \multirow[b]{2}{*}{ Sig } & \multirow[b]{2}{*}{ MD } & \multicolumn{2}{|c|}{$95 \%$} \\
\hline & & & & & & lower & Upper \\
\hline 1 & $\begin{array}{l}\text { Cara menentukan } \\
\text { beneficiary }\end{array}$ & 2,146 & 69 & 0,024 & 0,2967 & 0,2192 & 0,3741 \\
\hline 2 & $\begin{array}{l}\text { Peruntukan } \\
\text { bantuan }\end{array}$ & $-0,981$ & 69 & 0,233 & 0,0243 & $-0,131$ & 0,1796 \\
\hline 3 & Aparat desa & 2,803 & 69 & 0,398 & 0,0287 & 0,1944 & 0,2230 \\
\hline 4 & $\begin{array}{l}\text { Ketrampilan } \\
\text { pengelola grogram }\end{array}$ & 0,120 & 69 & 0,043 & $-0,0268$ & $-0,210$ & 0,1563 \\
\hline 5 & $\begin{array}{l}\text { Asal data penerima } \\
\text { bantuan }\end{array}$ & 1,798 & 69 & 0,210 & 0,2147 & 0,1981 & 0,2314 \\
\hline
\end{tabular}

t-tabel: 1, 243

Sumber: Data primer, diolah (2014)

Pada penelitian ini pertanyaan dibatasi pada pelaksanaan Program Nasional Pemberdayaan Masyarakat (PNPM) Mandiri. Meski demikian untuk mengeksplorasi jawaban tentang penerima bantuan, responden dibebaskan untuk menyampaikan semua pengalamannya terkait bantuan pemerintah termasuk Program Raskin dan Bantuan Langsung Tunai (BLT).

Hasil pengujian t-test per item untuk variabel Penyelenggara Kebijakan dapat dilihat dalam Tabel 4. Dari tabel tersebut dapat dilihat bahwa hanya satu variabel yaitu besarnya bantuan memiliki t-hitung lebih besar dari t-tabel. Dengan 
demikian disimpulkan bahwa dari variabel bantuan, responden menganggap jumlah bantuan akan menentukan efektivitas program sementara besarnya bunga dan tempo pembayaran bukan merupakan pertimbangn penting.

\section{Tabel 4}

\section{T-test Per Item untuk Variabel Konten}

\begin{tabular}{|c|c|c|c|c|c|c|c|}
\hline \multirow{4}{*}{ No. } & \multicolumn{7}{|c|}{ Program } \\
\hline & \multirow{3}{*}{ Item pertanyaan } & \multicolumn{6}{|c|}{ T-Test } \\
\hline & & \multirow[b]{2}{*}{$\mathrm{T}$} & \multirow[b]{2}{*}{ Df } & \multirow[b]{2}{*}{ Sig } & \multirow[b]{2}{*}{ MD } & \multicolumn{2}{|c|}{$95 \%$} \\
\hline & & & & & & Lower & Upper \\
\hline 1 & $\begin{array}{l}\text { Jumlah bantuan/ } \\
\text { pinjaman }\end{array}$ & 1,903 & 69 & 0,217 & 0,3495 & 0,2978 & 0,4012 \\
\hline 2 & Bunga pinjaman & 1,174 & 69 & 0,038 & $-0,9826$ & $-1,022$ & $-0,9432$ \\
\hline 3 & $\begin{array}{l}\text { Jatuh tempo } \\
\text { pembayaran }\end{array}$ & $-0,093$ & 69 & 0,155 & $-0,1637$ & -2.401 & $-0,8731$ \\
\hline
\end{tabular}

t-tabel: 1, 671

Sumber: Data primer, diolah (2014)

Hasl pengujian t-test per Untuk variabel Penyelenggara Kebijakan dapat dilihat dalam Tabel 5. Dari tabel tersebut dapat dilihat bahwa semua item dari variabel ini memiliki t-hitung lebih basar dari t-tabel sehingga hal ini mengkonfirmasi bahwa responden menganggap variabel Penyelenggara Program merupakan bagian penting yang menentukan keberhasilan suatu kegiatan. Bagian ini merupakan temuan utama dalam kajian ini karena mengkonfirmasi hipotesis yang diajukan berdasarkan pengumpulan data awal bahwa faktor penyelenggara program kegiatan suatu kebijakan berperan penting dalam implementasi suatu kegiatan. Efektivitas program akan bisa dicapai dengan adanya transparansi kegiatan yang hanya bisa dilaksanakan oleh pelaku kebijakan yang membangun dan memiliki kedekatan secara personal dengan penerima bantuan sehingga sosialisasi program yang transparansi dan fairness atas kegiatan tersebut bisa dijaga.
Tabel 5

T-test Per Item untuk Variabel Transparansi dan Pendekatan Personal petugas.

\begin{tabular}{|c|c|c|c|c|c|c|c|}
\hline \multirow{3}{*}{ No. } & \multirow{3}{*}{ Item pertanyaan } & \multicolumn{6}{|c|}{ T-Test } \\
\hline & & \multirow[b]{2}{*}{$\mathrm{T}$} & \multirow[b]{2}{*}{$\mathrm{Df}$} & \multirow[b]{2}{*}{ Sig } & \multirow[b]{2}{*}{ MD } & \multicolumn{2}{|c|}{$95 \%$} \\
\hline & & & & & & Lower & Upper \\
\hline 1 & $\begin{array}{l}\text { Peran aktif } \\
\text { dan kedekatan } \\
\text { personal }\end{array}$ & 2,179 & 69 & 0.014 & 0,3892 & 0,3103 & 0,4680 \\
\hline 2 & $\begin{array}{l}\text { Petugas thd } \\
\text { transparansi } \\
\text { program }\end{array}$ & 2,166 & 69 & 0,039 & 0,3910 & 0,2911 & 0,4910 \\
\hline 3 & $\begin{array}{l}\text { Fairness dlm } \\
\text { melaksanakan } \\
\text { program }\end{array}$ & 1,980 & 69 & 0,487 & 0,3112 & 0,2177 & 0,4062 \\
\hline
\end{tabular}

t-tabel: 1, 649

Sumber: Data primer, diolah (2014)

Ringkasnya, item dalam indikator program pemerintah menurut persepsi responden sebagai penerima bantuan yang dianggap penting adalah sebagai berikut (1) Transparansi Program, (2) Kedekatan personal dengan Petugas, (3) Fairness, (4) Cara menentukan beneficiary , (5) Jumlah bantuan, (6) Aparat desa (7) Ketrampilan pengelola grogram (8) Asal data penerima bantuan, (9) Peruntukan bantuan, (10) besarnya Bunga dan (11) Jatuh tempo. Tiga indikator yang terpenting dari sebelas item tersebut adalah: fairness, transparansi program dan kedekatan personal antara petugas dan penerima bantuan. Hal ini juga dikonfirmasi dan ditegaskan kembali melalui FGD dengan masyarakat penerima bantuan.

\section{KESIMPULAN DAN SARAN}

Kajian empiris dan teori menunjukkan bahwa pemerintah belum cukup menciptakan program yang memang dibutuhkan masyarakat UKM. Kebijakan berulang yang lebih menekankan pada pemberian modal berupa dana segar dilakukan karena menguntungkan pihak birokrat. Data kajian ini membuktikan bahwa masyarakat memiliki komitmen lebih tinggi pada saat bekerjasama dengan institusi keuangan/ simpan pin- 
jam non pemerintah meskipun harus membayar bunga pinjaman. Sebaliknya, masyarakat justru cenderung permisif dan tidak berkomitmen ketika mendapat bantuan pinjaman modal tanpa bunga dari pemerintah.

Dari pemaparan tersebut dapat disimpulkan beberapa hal mengenai pengembangan dan peningkatan UKM di Indonesia yaitu: (a) masyarakat miskin adalah subyek kebijakan dan bukan obyek dari program pemerintah. Dengan demikian masyarakat miskin akan dapat menolong dirinya sendiri selama pemerintah tidak mempersulit dengan menjadikannya obyek dan melakukan fungsi pengawasan dengan baik. Pelaku UKM akan bekerja lebih produktif dan berdaulat ketika mereka merasa bertanggung jawab dengan produktivitas usahanya dan bukan menjadi sekedar beneficiaries suatu program, (b) tugas negara adalah memenuhi hak rakyat termasuk melakukan kegiatan ekonomi dengan memberikan regulasi yang berpihak. Dengan demikian regulasi UKM harus mampu memandirikan usaha kecil rakyat dan mewujudkan kedaulatan. Kedua hal tersebut dapat dilakukan dengan melakukan kerja yang dibutuhkan pelaku usaha mikro, dan bukan apa yang mudah dan menguntungkan bagi pemerintah.

\section{DAFTAR PUSTAKA}

Ayyagari, M., T. Beck, Demirguc-Kunt, A. 2007. Small and Medium Enterprises Across the Globe. Small Business Economics (2007) 29: 415-434

Beckett, Julia. 2000. Early Budget Theory: The Progressive Theory of Public Expenditures. In Budget Theory in The Public Sector. Aman Khan and W. Bartley Hildreth (editors). Greenwood Publishing Group, Inc. Page 22-41

Bhagwati, J. N. 2011. Market and Morality. American Aconomic Review: Papers and Proceedings, 101:, 161-165
Budiani, N.W. 2009. Efektivitas Program Bantuan Kredit Usaha Rakyat (KUR) Terhadap Pendapatan dan Kesempatan Kerja Usaha Mikro Kecil dan Menengah (UKM). Jurnal Ekonomi dan Sosial INPUT Vol. 2. No. 1 pp: 49-57. 2009. Universitas Udayana.

Budiono G.L, Berdimuratova, L.T., Azahari A. 2013. Capitalism can reduce poverty. Revista Economica 65:6 (2013) page 1-11.

Chandrakumara, Anil. 2013. Human Resources Management Practices in Small and Medium Enterprises in Two emerging economies in Asia: Indonesia and South Korea. Small Enterprise Association of Australia and New Zealand 26th Annual SEAANZ Conference Proceedings 1112 Sydney 2013.

Elida, T dan Beny Susanti. 2009. Efektifitas Bergulirnya Program Bantuan P2KP: Studi kasus pada Kelurahan Pancoran Ms Depok, Jawa Barat. Jurnal Elektronik Vol. 14 No. 3 2009. Universitas Gunadharma.

Gollin, D. 2002. Getting Income Shares Right. Williams College.

Hamdania, J. dan Wirawan, C. 2012. Open Innovation Implementation to Sustain Indonesian SMEs. International Conference on Small and Medium Enterprises Development with a Theme (ICSMED 2012).

Mintohardjo, S. Menuju Welfare State Melalui Koperasi. Majalah Info Koperasi Edisi 24. Tahun 2004.

Pietrobelli, Carlo and Roberta Rabelotti. 2010. Upgrading to Compete Global Value Chains, Clusters, and SMEs in Latin America. Social Science Research Network. 
Rahardjo, Mudjia. 2010. Metode Triangulasi dalam Penelitian Kualitatif. Gagas Media Press Jakarta

Sanusi, A., Butler, B., Rola-Rubzen, MF. 2013. Local Politics and Business in Indonesia: A Non-market Strategy Approach

Sarosa, S. 2007. The Information Technology Adoption Process within Indonesian Small and Medium Enterprises. Dissertation. University of Technology Sydney. Faculty of Information Technology.

SMRJ Japan. 2008 .Small \& Medium Enterprise Development Policies in 6 ASEAN Countries. Published by Organization for Small \& Medium Enterprises. Japan

Swiss Economic Cooperation and Development. Indonesia Country Strategy 2013-2016Federal Department of Economic Affairs, Education and Research EAER. State Secretariat for Economic Affairs SECO. SWISS.

Timberg, Thomas A. 2000. The Political Economy of SME Development Policy in Indonesi - the Policy Process, the Facts, and Future Possibilities. Small Credit Adviser, Bank Indonesia. Partnership for Economic Growth (PEG) Project1
Tullock, Gordon. 2005. Public Goods, Redistribution and Rent Seeking George Mason University, USA. The Locke Institute. Edward Elgar Cheltenham, US.

Turner, Sarah. 2007.Small-ScaleEnterpriseLivelihoodsandSocialCapitalin Eastern Indonesia:Ethnic Embeddedness and Exclusion. The Professional Geographer: Volume 59, Number 4, November 2007. Pp 408 - 420

Wacana. 2012. Indonesia 2014 Calon Presiden Kita: Tentang 36 nama yang mungkin memimpin Indonesia 2014.

White, Benjamin. 2002. Inti dan Plasma:Pertanian Kontrak dan Pelaksanaan Kekuasaan di Dataran Tinggi Jawa Barat. Dalam Tania Murray Li (ed) Proses Transformasi Daerah Pedalaman di Indonesia. Yayasan Obor Indonesia.

Yustika, A.E. 2011. Ekonomi Politik : Kajian Teoritis dan Analisi Empiris. Pustaka Pelajar. Yogyakarta.

www.depkop.go.id 